\title{
Dietary niche divergence between two invasive fish in Mediterranean streams
}

\author{
Christos Gkenas ${ }^{1, *}$, a, Maria Filomena Magalhães ${ }^{2, a}$, Julien Cucherousset ${ }^{3}$, Rafael Leonardo Orjuela ${ }^{1,4}$ \\ and Filipe Ribeiro ${ }^{1}$ \\ ${ }^{1}$ MARE, Centro de Ciências do Mar e do Ambiente, Faculdade de Ciências, Universidade de Lisboa, Campo Grande, 1749-016 Lisboa, \\ Portugal \\ ${ }^{2}$ cE3c, Centro de Ecologia, Evolução e Alterações Ambientais, Faculdade de Ciências, Universidade de Lisboa, 1749-016 Lisboa, \\ Portugal \\ ${ }^{3}$ CNRS Université Toulouse III Paul Sabatier UMR5174 EDB (Laboratoire Évolution Diversité Biologique), 118 route de Narbonne, \\ 31062 Toulouse, France \\ ${ }^{4}$ Facultad de Medicina Veterinaria y de Zootecnia, Universidad Nacional de Colombia, Bogotá D.C., Colombia
}

Received: 3 March 2019 / Accepted: 28 April 2019

\begin{abstract}
Clarifying the mechanisms associated with the coexistence of invasive species is important to understand the overall impact of multiple invasions on recipient communities. Here we examined whether divergence or convergence in dietary niche occurred when invasive Lepomis gibbosus and Australoheros facetus coexist in Iberian streams. We used stomach content analyses to determine dietary niche composition, width, and overlap in allopatric and sympatric counterparts in the Lower Guadiana throughout the dry-season. The variations in dietary niche between pumpkinseed and the cichlid were consistent with predictions derived from the niche divergence hypothesis. Although there were no changes in the use of plant material from allopatry to sympatry in either species, sympatric pumpkinseed and the cichlid displayed marked shifts in the use of animal prey and a decrease in niche width relative to allopatric counterparts. Moreover, sympatric pumpkinseed and cichlid showed similar niche width but differed significantly in plant and animal prey use. Taken together these results suggest that divergence in dietary niches may play a role in mediating coexistence of multiple invaders in Iberian streams.
\end{abstract}

Keywords: species coexistence / biological invasions / trophic ecology / sympatry / allopatry

Résumé - Divergence de niche trophique de deux poissons invasifs dans les rivières méditerranéennes. Comprendre les mécanismes associés à la coexistence des espèces invasives est important pour comprendre les effets des invasions multiples. Ici, nous avons évalué l'existence possible de divergence ou de convergence de niche trophique lorsque de Lepomis gibbosus et de Australoheros facetus invasives coexistent dans des rivières de la péninsule Ibérique. Nous avons analysé des contenus stomacaux pour déterminer la composition, la taille et le chevauchement des niches trophiques dans les zones allopatriques et sympatriques de la zone aval de la rivière Guadiana, pendant la saison sèche. Les variations de niche trophique observées entre la perche soleil et le cichlidé indique une potentielle divergence de niche. Bien qu'il n'y ait pas eu de changement dans l'utilisation des ressources végétales, les perches soleil et cichlidé sympatriques présentaient des changements marqués dans l'utilisation des proies animales avec une diminution de la taille de la niche par rapport aux individus allopatriques. De plus, les perches soleil et cichlidés sympatriques avaient une taille de niche similaire mais utilisaient différemment les ressources animales et végétales. Ces résultats suggèrent que des divergences de niches trophiques peuvent jouer un rôle dans la coexistence des envahisseurs multiples dans les rivières ibériques.

Mots clés : coexistence d'espèces / invasions biologiques / écologie trophique / sympatrie / allopatrie

\footnotetext{
*Corresponding author: chrisgenas@gmail.com

a These authors have contributed equally to this work.
} 


\section{Introduction}

Accelerating rates of biological invasions are resulting in communities being subjected to multiple introductions, with invasive species increasingly coexisting outside of their native range (Jackson and Grey, 2013; Seebens et al., 2017). Interactions among multiple invaders may be positive, as some invaders alter ecosystem conditions in favor of other invaders (Ricciardi 2001; Simberloff, 2006), negative, as strong competitive and predator invaders accumulate and limit establishment of new invaders (Ross et al., 2004; Johnson et al., 2009) or neutral, with no clear effect on invasion process (Cope and Winterbourn, 2004). Although this can have important implications for the overall impact of biological invasions (Orchan et al., 2013), our knowledge on the networks of ecological interactions among multiple invaders within recipient communities is still limited.

A key process modulating species coexistence is the ecological niche. According to niche theory, species with similar ecological niches should not coexist because competition should lead to the exclusion of the weaker species or the development of species-specific differences in resource use, with species specializing and consuming fewer alternative resources and thereby reducing niche widths (Schoener, 1974; Abrams, 1983; Chesson, 2000). However, the competitive exclusion principle has been increasingly challenged and potential alternative mechanisms to niche differentiation for coexistence have been advanced (Schoener, 1989; Wiens, 1993). Competitive coexistence with similar ecological niches might occur when sympatric species are similar in their skills to compete for a limited resource and neither can exclude the other (Keddy, 1989), and/nor if the resource is severely limited and species are forced to converge to exploit the remaining resources and overlap becomes high (Schoener, 1989; Wiens, 1993), with reductions in the frequency of preferred resource, leading to increased niche widths (Schoener, 1971; Stephens and Krebs, 1986).

Trophic interactions are recognized as one of the most important ecological processes by which invaders induce ecological impacts on recipient communities (Rosewarne et al., 2016). However, empirical investigations on the mechanisms that may facilitate coexistence of invader species with similar trophic niches remains scarce (but see Jackson and Britton, 2014). Moreover, evidence for species coexisting with similar trophic niche is controversial, with some studies indicating that sympatric species exhibit narrower dietary niches than their allopatric conspecifics (Bolnick et al., 2010; Jackson et al., 2012) and display broader niches when resources are abundant (Jackson and Britton, 2014; Rothhaupt et al., 2014), whereas other studies show that the dietary niche of sympatric species converge (Cucherousset et al., 2007; Gabler and Amundsen, 2010). Closer examination of the interplays between dietary niche, niche width and overlap among invaders in allopatric and sympatric situations is thus critical to clarify mechanisms allowing invasive species coexistence.

Mediterranean streams are ideal systems to examine mechanisms by which fish invaders may coexist. Indeed, there is a long history and accelerating rate of fish introductions in streams in the Mediterranean Basin (e.g. Clavero et al., 2010;
Hermoso and Clavero, 2011), with multiple invaders of variable origins and ecological niches coexisting in space and time (Vila-Gispert et al., 2005; Ribeiro et al., 2008). Moreover, Mediterranean streams are mostly shaped by annual drought events, with concentration of fish in reduced space likely strengthening competition for limited food resources among species (Magalhães, 1993a; Magalhães et al., 2002). Nevertheless, current knowledge on the trophic ecology of invasive fish during the dry-season is limited (but see Godinho et al., 1997; Ribeiro et al., 2007) and determining if dietary niche divergence is observed when invasive species coexist are important.

Here, we quantified variations in dietary niche between allopatric and sympatric pumpkinseed sunfish Lepomis gibbosus (Linnaeus) and chameleon cichlid Australoheros facetus (Jenyns), in the Lower Guadiana Basin, in southern Iberian Peninsula. We selected the pumpkinseed and the cichlid as model species because they are highly invasive and have established populations in the area (Ribeiro et al., 2009), are similar in size, lifespan and parental care traits (Ribeiro et al., 2008) and have been demonstrated to impact recipient communities (e.g. García-Berthou and Moreno-Amich, 2000; Almeida et al., 2014). The evidence available from singlespecies studies indicates that pumpkinseed and the cichlid display some variations in dietary niche, differing in the use of plant material but preying on similar macroinvertebrates (Godinho et al., 1997; Ribeiro et al., 2007; Gkenas et al., 2016). However, food resource use and dietary niche of the two species when in sympatry have never been quantified, particularly during the dry season, when macroinvertebrates tend to be in short supply (Pires et al., 2000).

Specifically, we tested two hypotheses and their attendant predictions to clarify mechanisms allowing coexistence of invasive pumpkinseed and chameleon cichlid. We first hypothesized that niche divergence was associated with invader coexistence and predicted that:

i. resource use by one or the two species differs between allopatry and sympatry, resulting in variations in dietary niche and low niche overlap between the two species when in sympatry and;

ii. niche width is narrower in sympatry than in allopatry.

Alternatively, we hypothesized that niche convergence and/or limited resources regulate the coexistence of invaders and we predicted that:

i. the two species converge to exploit the same resources when in sympatry, occupying similar dietary niche and showing high niche overlap, and;

ii. niche width is broader in sympatry than in allopatry.

\section{Materials and methods}

\subsection{Study area and model species}

The Lower Guadiana Basin (hereafter LGB; $37^{\circ}-39^{\circ}$ $30 \mathrm{~N}, 7^{\circ}-8^{\circ} \mathrm{W}$ ) is described in detail elsewhere (Ribeiro et al., 2007; Ribeiro and Collares-Pereira, 2010). Briefly, the LGB is $11.700 \mathrm{~km}^{2}$, and drains mainly schist-derivate rocks, and highly impermeable soils, with little groundwater. Climate is typically Mediterranean, with mean monthly temperature 
ranging from $9.3{ }^{\circ} \mathrm{C}$ (January) to $24.4{ }^{\circ} \mathrm{C}$ (July). Annual rainfall varies markedly from year to year $(333-1.044 \mathrm{~mm})$, but $80 \%$ of the rain occurs between October and March and there is virtually no rain from June to September. The flow regime is highly dependent on rainfall patterns, with floods occurring in winter and early spring and low or zero flows prevailing in summer and early fall. Throughout the dryseason, flow may persist in the main-stem and the largest tributaries, but smaller tributaries typically dry to isolated pools. Fish assemblages include a pool of 11 native species, 10 of which are threatened, and 11 non-native species, 7 of which are restricted to reservoirs and regulated downstream reaches.

The model species have long been established in the LGB but show considerable differences in distribution and abundance patterns. The pumpkinseed, native to the Great Lakes region in North America, was first recorded in 1979 (Almaça, 1983), and is currently abundant across most of the basin, except of few locations in the southern tributaries. Conversely, the cichlid, native to South America, was first recorded in 1962 (Ribeiro et al., 2009), and occurs only in the main-stem and some southern tributaries, seldom in high abundance. Both species are generally less than $13 \mathrm{~cm}$ in total length (TL), live up to 7 years and mature in 2 years, and build and guard spawning nests and fry (Rios-Cardenas and Webster, 2005; Ribeiro et al., 2008; Ribeiro and Collares-Pereira, 2010). The pumpkinseed is invertivore whereas the cichlid is omnivore, though both prey upon macroinvertebrates, shifting from small, soft-bodied towards large, hard-shelled prey during ontogeny (Godinho et al., 1997; Ribeiro et al., 2007, Gkenas et al., 2016).

\subsection{Fish sampling}

Fish samples were collected throughout the dry-season of 2003 at three sites, one in the Degebe $(-7.690 \mathrm{E}, 38.478 \mathrm{~N})$, one in the Vascão $(-7.621 \mathrm{E} ; 37.489 \mathrm{~N})$ and one in the Ardila rivers $(-7.301 \mathrm{E}, 38.148 \mathrm{~N})$. Sampling location was constrained by the distribution of the model species, with pumpkinseed and the cichlid occurring in allopatry in the Degebe and Vascão, respectively, and in sympatry in the Ardila. Other fish species also occurred in the sampling sites, but local assemblages were generally similar, being dominated by native barbels and non-native mosquitofish. Pumpkinseed and the cichlid were also equally abundant in the Ardila (Ribeiro F., unpublished data). There were also some variations in stream flow, width, depth and water temperature among sites (Supplementary Table 1), with the Degebe and Vascão rivers being reduced to isolated pools, whereas the Ardila river maintained persistent flow throughout the dryseason. Nevertheless, rainfall in the LGB $\left(37^{\circ} 94^{\prime} \mathrm{N}, 7^{\circ} 60^{\prime} \mathrm{W}\right)$ between October 2002 and September 2003 was close to the long-term annual median since 1980 (485 vs. $484.4 \mathrm{~mm}$; www. snirh.pt), causing dry-season conditions to be less severe and heterogeneous among sites than in drier years.

Fish sampling was conducted early in May and June, when flow conditions were still similar among sites, and in August and September, shortly before rains. Each month, sampling was conducted during consecutive days, in the morning, to avoid circadian variations in the diet. At each site, a 200-m reach was sampled using a single anode electrofishing gear ( $300 \mathrm{~V}, 2-3 \mathrm{~A}, \mathrm{DC})$, always operated by the same person. All individuals were euthanized by immersion in tricaine methanesulfonate (MS-222), and placed on ice, and later deep-frozen $\left(-20^{\circ} \mathrm{C}\right)$. To minimize variation due to ontogenetic diet shifts, we restricted our analysis to adult individuals (60-90 $\mathrm{mm}$, standard length).

\subsection{Diet analysis}

Diet data for the cichlid were previously reported by Ribeiro et al. (2007), and for consistency, we used the same methods to gather diet data for the pumpkinseed. In brief, fish were dissected, stomachs were opened and assessed for fullness, and individuals with empty stomachs were excluded from the analyses. Food contents were spread on gridded Petri dishes and examined under a binocular dissecting microscope. Plant material (i.e. algae, vascular plant parts, and seeds) was recorded and its proportional contribution in terms of area to the stomach contents was estimated by eye. Animal prey items were identified to the lowest readily recognizable taxon and counted.

In total, 60 pumpkinseed and 58 cichlid individuals with non-empty stomachs were used in the analyses, with sample sizes per site varying between 11 and 22 individuals (Fig. 1). Selected individuals had enough prey items for analysis (>3; Bowen, 1996) and prey counts were not significantly related to fish standard length in both pumpkinseed $(P=0.450)$ and the cichlid $(P=0.168)$. A total of 5734 prey items were identified, indicating that the prey sample sizes likely provided sufficient power in analyses, given the small length range of fish used. For analysis, prey items were grouped into ten categories: Chironomidae, Ephemeroptera, Hemiptera, Trichoptera, Ostracoda, Cladocera, Copepods, Hydracarina, Mollusca, and other. These categories were defined following taxonomic affinities, so that each category contributed to $>1 \%$ of the total prey at least for one of species, and at one site. The category "other" comprised rare and unidentified prey.

\subsection{Data analysis}

To test the predictions of the two alternative niche hypotheses, our analyses focused on detecting variations in dietary niche composition and niche width for each species between allopatry and sympatry, and in characterizing dietary niche composition, width and overlap between species when in sympatry. Because food resource supply and fish diets may vary over the dry-season (e.g. Godinho et al., 1997; Pires et al., 2000; Ribeiro et al., 2007), two separate sets of analyses were conducted for the early (May-June) and the late dry-season (August-September). Unless otherwise indicated, analyses were conducted using the R software (v.3.4.2, R Development Core Team, 2017), and significance of statistical testing was assessed at $P<0.05$.

Variation in dietary niche composition was evaluated using both plant material and animal prey. Specifically, we tested for differences in the frequency of occurrence (FO) and in the proportional area (PA) of plant material between allopatric and sympatric counterparts and between species using the chi-squared test of independence and the Mann- 

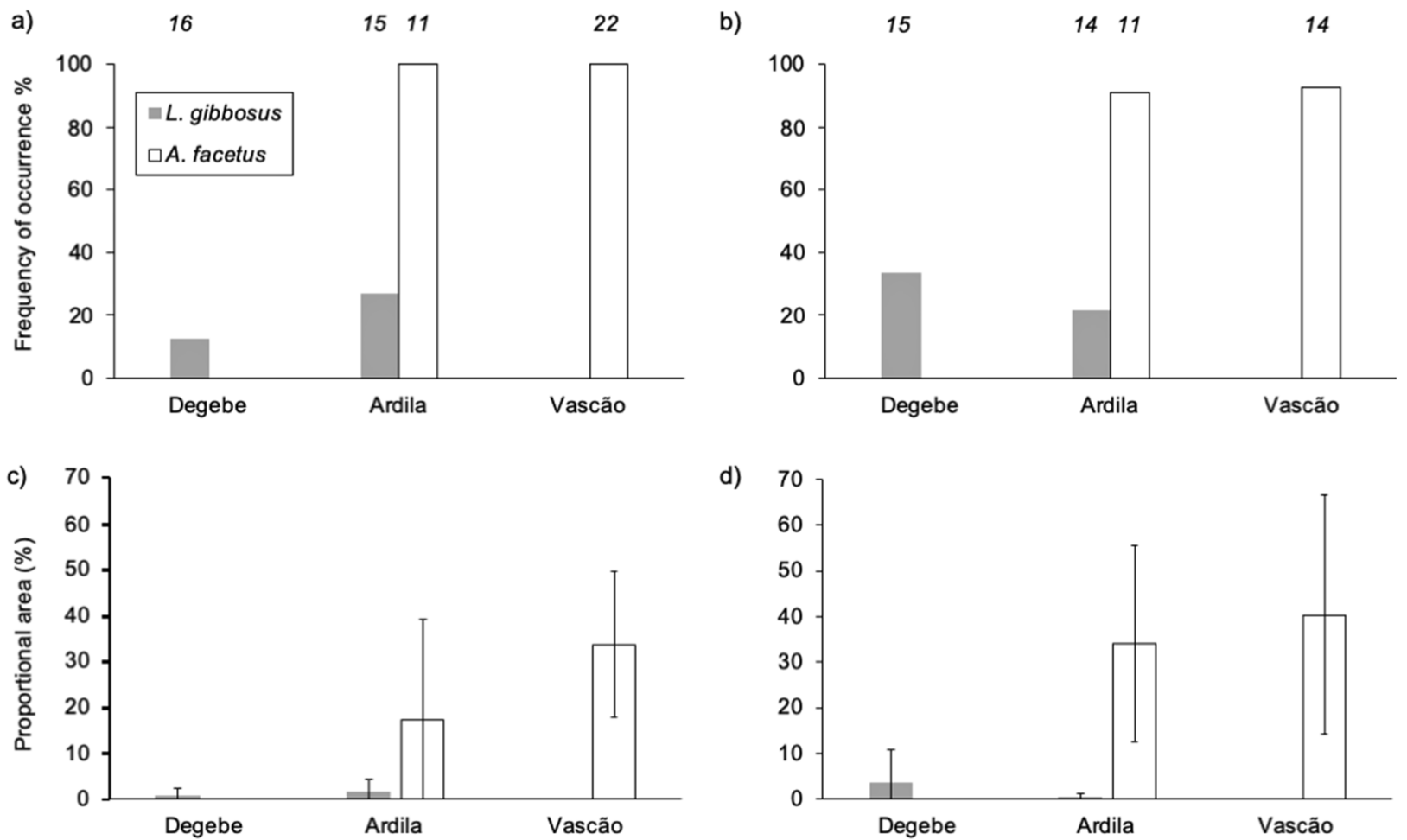

Fig. 1. Plant material in the diet of pumpkinseed Lepomis gibbosus and the cichlid Australoheros facetus in allopatric (Degebe and Vascão) and sympatric (Ardila) sites in the Lower Guadiana Basin throughout the dry-season. Upper-panels frequency of occurrence of plant material in the diet in the early (a) and late (b) dry-season; lower panels proportional area (mean $\pm \mathrm{SD}$ ) of plant material in the diet in the early (c) and late (d) dry-season. The values above each column are the number of individuals with the non-empty stomachs analysed (n, in italics).

Whitney test, respectively. We summarized variation in animal prey proportions using Non-Metric Multidimensional Scaling (NMDS) based on the Bray-Curtis similarity index (Clarke et al., 2014). Prior to analysis, data were square-root transformed to reduce the influence of abundant prey. The NMDSs (PCs) were taken as niche dimensions, that typically represent gradients in prey use. Because low stress values $(<0.2)$ indicated that two-dimensional axes were sufficient to achieve reliable and robust separation of the data (Clarke et al., 2014), we contrasted the main structure of prey use between groups using NMDS1 and NMDS2 scores.

Analysis of Similarity (ANOSIM) was used to test the null hypothesis of no difference in prey use between groups. In this analysis, the Global-R statistics ranges from zero to one, indicating no and complete separation between groups, respectively. The significance level of the $\mathrm{R}$ statistics was calculated using a procedure including 5000 permutations of the dataset and was corrected for multiple testing using Bonferroni sequential method. We used the $\mathrm{R}$ values derived from ANOSIM to assess overlap in animal prey use. Specifically, $\mathrm{R}$ values $\leq 0.25$ were considered to represent substantial overlap, values $0.26-0.5$ moderate overlap, and values $>0.5$ little to no overlap in prey use (Creque and Czesny, 2012). Finally, similarity percentage (SIMPER) analysis (Clarke, 1993) was used to examine the contribution of each prey category for dissimilarities in prey use between groups. Prey categories were listed in decreasing order by their average contribution to the total average dissimilarity, with a cut-off at $50 \%$ of cumulative average dissimilarity.

Dietary niche width was quantified based on animal prey only, using the Shannon-Wiener index, as:

$$
H=-\sum_{i}^{n} p_{i} \cdot \log \left(p_{i}\right),
$$

where $p_{i}$ is the proportion of prey category $i$ in a given species' diet, and $n$ is the number of prey categories. The index ranges from zero to $\infty$, increasing with the number and evenness of prey categories in the diet (Colwell and Futuyma, 1971). To evaluate variation in niche width between groups, we resampled the dataset 5000 times and calculated bootstrapped 95\% confidence intervals around the index. We considered that non-overlapping confidence intervals indicated significant differences in niche width, and that otherwise differences were not significant.

\section{Results}

There was considerable variation between pumpkinseed and the cichlid in the use of plant material and animal prey. The diet of pumpkinseed included plant material (FO: 12.5 $33.3 \%$ ) but always in low proportions (PA: 0.4-3.6\%), while 

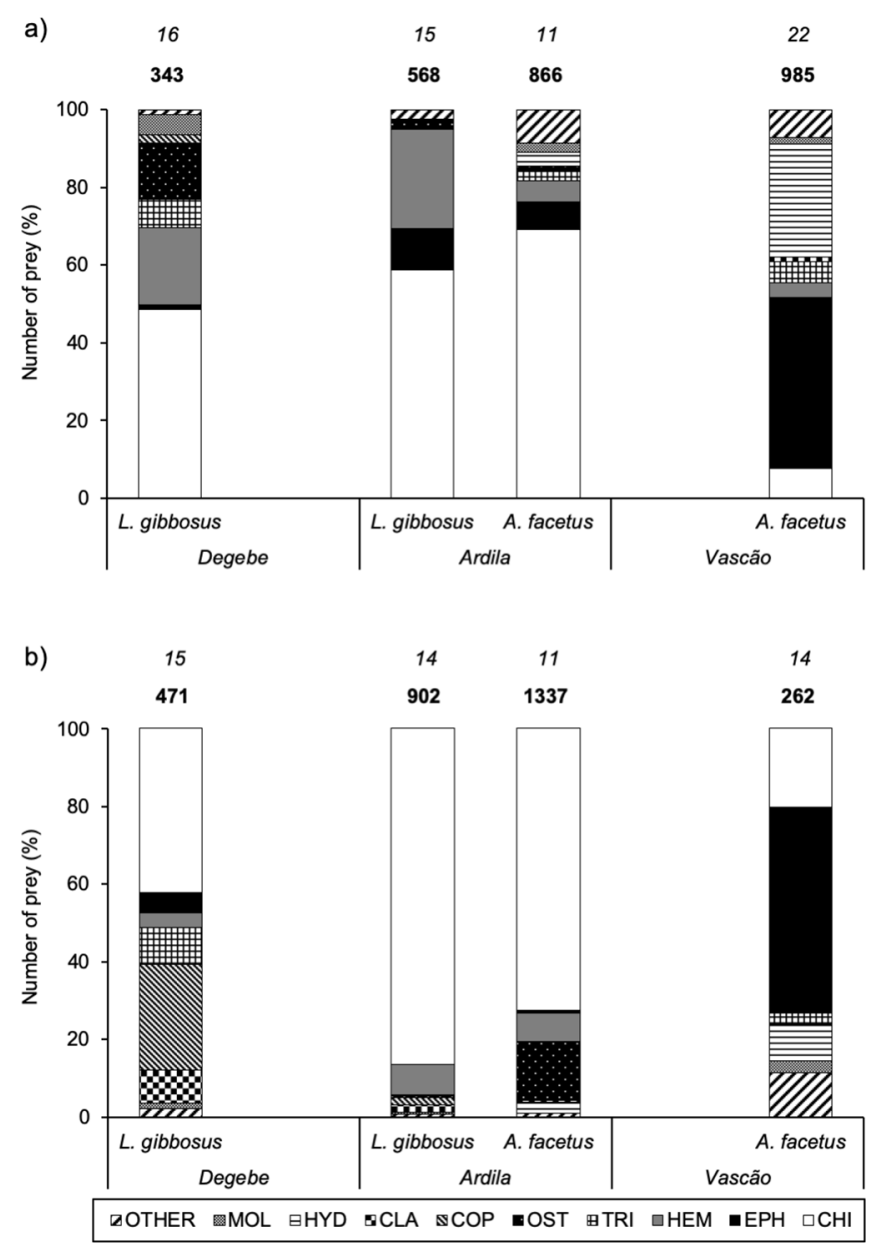

Fig. 2. Percent contributions by number of each prey category to the diet of pumpkinseed Lepomis gibbosus and the cichlid Australoheros facetus in allopatric (Degebe and Vascão) and sympatric (Ardila) sites in the Lower Guadiana Basin, during the early (a) and late (b) dryseason. The values above each column are the number of individuals with non-empty stomachs (n, in italics) and the number of prey items (N, in bold) in each sample. Prey code are: $\mathrm{CHI}$, Chrironomidae; $\mathrm{EPH}$, Ephemeroptera; HEM, Hemiptera; TRI, Trichoptera; OST, Ostracoda; CLA, Cladocera; COP, Copepoda; HYD, Hydracarina; MOL, Mollusca; Other, Other prey.

this was very frequent in the diet of the cichlid (FO: 90.9$100 \%$ ) and often in high proportions (PA: 17.3-40.4\%; Fig. 1). In overall, both pumpkinseed and the cichlid preyed mostly on Chironomidae (64.8\% and $49.2 \%$, respectively), with other prey contributing to $>10 \%$ of the diet including Hemiptera $(13.2 \%)$ and Copepoda $(6.7 \%)$ for pumpkinseed and Ephemeroptera (18.7\%) and Hydracarina (11.1\%) for the cichlid (Fig. 2). In allopatry, pumpkinseed consumed mostly Chironomidae (42.3-48.7\%) and used also Hemiptera $(19.8 \%)$ and Ostrocada $(14.6 \%)$ early in the dry-season and Copepoda $(27.2 \%)$ late in the dry-season whereas the cichlid preyed mostly on Ephemeroptera (44.2-52.7\%) and used high proportions of Hydracarina (29.2\%) early in the dry-season and of Chironomids (20.2\%) and Other prey $(11.5 \%)$ late in the dry-season. In sympatry, Chironomidae were prevalent in the diet of both pumpkinseed $(58.8-86.4 \%)$ and the cichlid (69.3-72.4\%), particularly late in the dry-season. Hemiptera $(25.5 \%)$ and Ostracoda (14.9\%) were also consumed in high numbers by pumpkinseed early in the dry-season and by the cichlid late in the dry-season, respectively.

\subsection{Dietary niche in allopatry and in sympatry}

There were no significant differences in the frequency of occurrence (FO) and the proportion (PA) of plant material in the diet between allopatry and sympatry neither for pumpkinseed in the early (FO: $\chi^{2}=2.548, P=0.474$; PA: U-test $=$ $103.000, P=0.520)$ and in the late dry-season $\left(\chi^{2}=0.514\right.$, $P=0.474$; U-test $=122.00, P=0.477$ ) nor for the cichlid in the early $\left(\chi^{2}=0.516, P=0.473\right.$; U-test $\left.=262.50, P=0.278\right)$ and late dry-season $\left(\chi^{2}=0.032, \quad P=0.859 ; \quad\right.$ U-test $=88.50$, $P=0.536$ ). Conversely, there was considerable variation in animal prey use between allopatry and sympatry for both species, but most notably for the cichlid (Fig. 3). Early in the dry-season, NMDS1 scores for the cichlid in allopatry tended to differentiate from those in sympatry, but no similar tendency was found for pumpkinseed. Conversely, late in the dryseason, there was a much stronger separation in the ranges of NMDS1 scores of allopatric and sympatric cichlid, and NMDS1 scores for pumpkinseed in allopatry also tended to differentiate from those in sympatry. No variation was found between the ranges of NMDS2 in allopatry and sympatry for both species throughout the dry-season. The ANOSIM corroborated the existence of significant variations in animal prey use between allopatry and sympatry for both species early and late in the dry-season (Tab. 1), indicating that the separation was major for the cichlid late in the dry-season $(\mathrm{R}=0.85)$ but also marked early in the dry-season $(\mathrm{R}=0.44)$. For both species, dissimilarities in animal prey use between allopatry and sympatry were consistently related to contributions of Chironomidae (17.43-21.91\%), but Hemiptera (15.82-21.93\%) and Ephemeroptera (13.40-28.29\%) were also important contributors in the case of pumpkinseed and the cichlid, respectively (Tab. 1). Additional prey with important contributions early in the dry-season included Ostracoda $(20.55 \%)$ for pumpkinseed.

There was considerable variation in niche width between allopatry and sympatry for the pumpkinseed and a slighter tendency was also found for the cichlid (Fig. 4). Bootstrapped 95\% confidence intervals for the Shannon-Wiener indicated that niche width for pumpkinseed was narrower in sympatry than in allopatry, early $(\mathrm{H}=0.69 v s .0 .92)$ and particularly late $(\mathrm{H}=0.39$ vs. 0.91$)$ in the dry-season, and that sympatric cichlid also displayed a decrease in niche width relative to allopatry during the late period $(\mathrm{H}=0.68$ vs. 0.93).

\subsection{Dietary niche variation between species when in sympatry}

There were significant differences in the frequency of occurrence and the proportion of plant material in the diet between sympatric pumpkinseed and the cichlid (Fig. 1), both early $\left(\chi^{2}: 12.185, P<0.001, d f=1\right.$; U-test $\left.=9.50, P<0.001\right)$ and late in the dry-season $\left(\chi^{2}: 11.914, P<0.001\right.$; U-test $=8.50$, $P<0.001)$. 

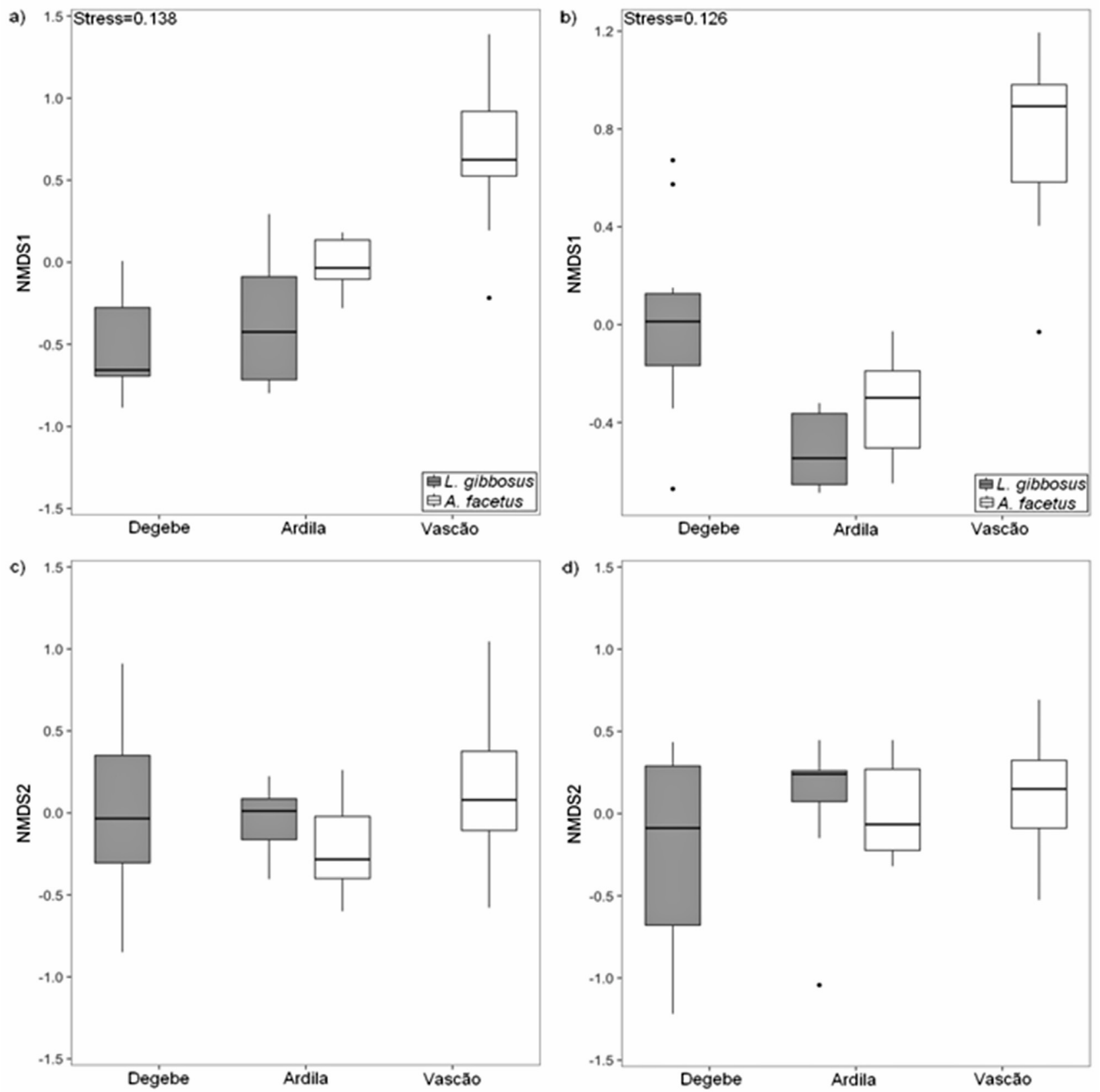

Fig. 3. Box plots illustrating variation in the first and second NMDS scores for animal prey in the diet of pumpkinseed Lepomis gibbosus and the cichlid Australoheros facetus in allopatric (Degebe and Vascão) and sympatric (Ardila) sites in the Lower Guadiana Basin (Portugal) during the early (a) and (c) and the late (b) and (d) dry-season. The box represents the interquartile range (IQR; 25th and 75th percentiles), and the line within the box is the median. Whiskers represent the 75th percentile $+1.5 x \mathrm{IQR}$ and the 25 th percentile $+1.5 x \mathrm{IQR}$. Data beyond the end of the whiskers are outliers and plotted as points. The stress values for each NMDS are given in the upper panels (a) and (b).

There was also some variation in animal prey use between species throughout the dry-season (Fig. 2). Although NMDS scores showed no marked contrasts between species throughout the dry-season (Fig. 3), ANOSIM results indicated that variations in animal prey use between species were significant both in the early $(\mathrm{R}=0.28)$ and late $(\mathrm{R}=0.23$; Tab. 1) dryseason, though overlap in animal prey was still moderate to high. Dissimilarities in animal prey use were mostly related to contributions of Hemiptera (23.66-24.56\%), with other contributors including Ephemeroptera (18.12\%) and other prey $(18.59 \%)$ early in the dry-season and Ostracoda $(24.33 \%)$ and Chironomidae $(14.00 \%)$ late in the dry-season (Tab. 1). Prey niche width also did not differ between pumpkinseed and cichlid when in sympatry throughout the dry-season (Fig. 4).

\section{Discussion}

The variations in the dietary niche of invasive pumpkinseed and the cichlid found in this study were consistent with predictions derived from the niche divergence hypothesis. 
Table 1. Results of the ANOSIM and SIMPER analyses of animal prey in the diet of allopatric and sympatric pumpkinseed Lepomis gibbosus and the cichlid Australoheros facetus in the Lower Guadiana Basin (Portugal) throughout the dry-season. Asterisks represent significant differences in pairwise comparisons of animal prey proportions $(\mathrm{R})$ based on the sequential Bonferroni method $(\alpha=0.05, k=3)$. Prey categories contributing $>20 \%$ to average dissimilarity (AvD) are highlighted in bold and ranks of prey contributions are shown in brackets. Prey codes are: CHI, Chrironomidae; HEM, Hemiptera; EPH, Ephemeroptera; OST, Ostracoda; COP, Copepoda; HYD, Hydracarina; Other, Other prey.

\begin{tabular}{|c|c|c|c|c|c|c|c|c|c|}
\hline & $\mathrm{R}$ & AvD & $\mathrm{CHI}$ & EPH & HEM & OST & $\mathrm{COP}$ & HYD & OPREY \\
\hline \multicolumn{10}{|l|}{ Early dry-season } \\
\hline \multicolumn{10}{|l|}{ Allopatry vs. Sympatry } \\
\hline Pumpkinseed & $0.17 *$ & 48.61 & $17.43(3)$ & & 21.93(1) & $20.55(2)$ & & & \\
\hline Cichlid & $0.44 *$ & 58.59 & $26.99(1)$ & 21.02(2) & & & & $15.16(3)$ & \\
\hline \multicolumn{10}{|l|}{ Sympatry } \\
\hline Pumpkinseed vs. Cichlid & $0.28 *$ & 42.41 & & $18.12(3)$ & $23.66(1)$ & & & & $18.59(2)$ \\
\hline \multicolumn{10}{|l|}{ Late dry-season } \\
\hline \multicolumn{10}{|l|}{ Allopatry vs. Sympatry } \\
\hline Pumpkinseed & $0.22 *$ & 49.06 & $19.23(1)$ & $13.40(4)$ & $15.82(2)$ & & $14.89(3)$ & & \\
\hline Cichlid & $0.85^{*}$ & 69.16 & 21.91(2) & 28.29(1) & & & & & \\
\hline \multicolumn{10}{|l|}{ Sympatry } \\
\hline Pumpkinseed $v s$. Cichlid & $0.23 *$ & 34.05 & $14.00(3)$ & & $24.56(1)$ & $24.33(2)$ & & & \\
\hline
\end{tabular}
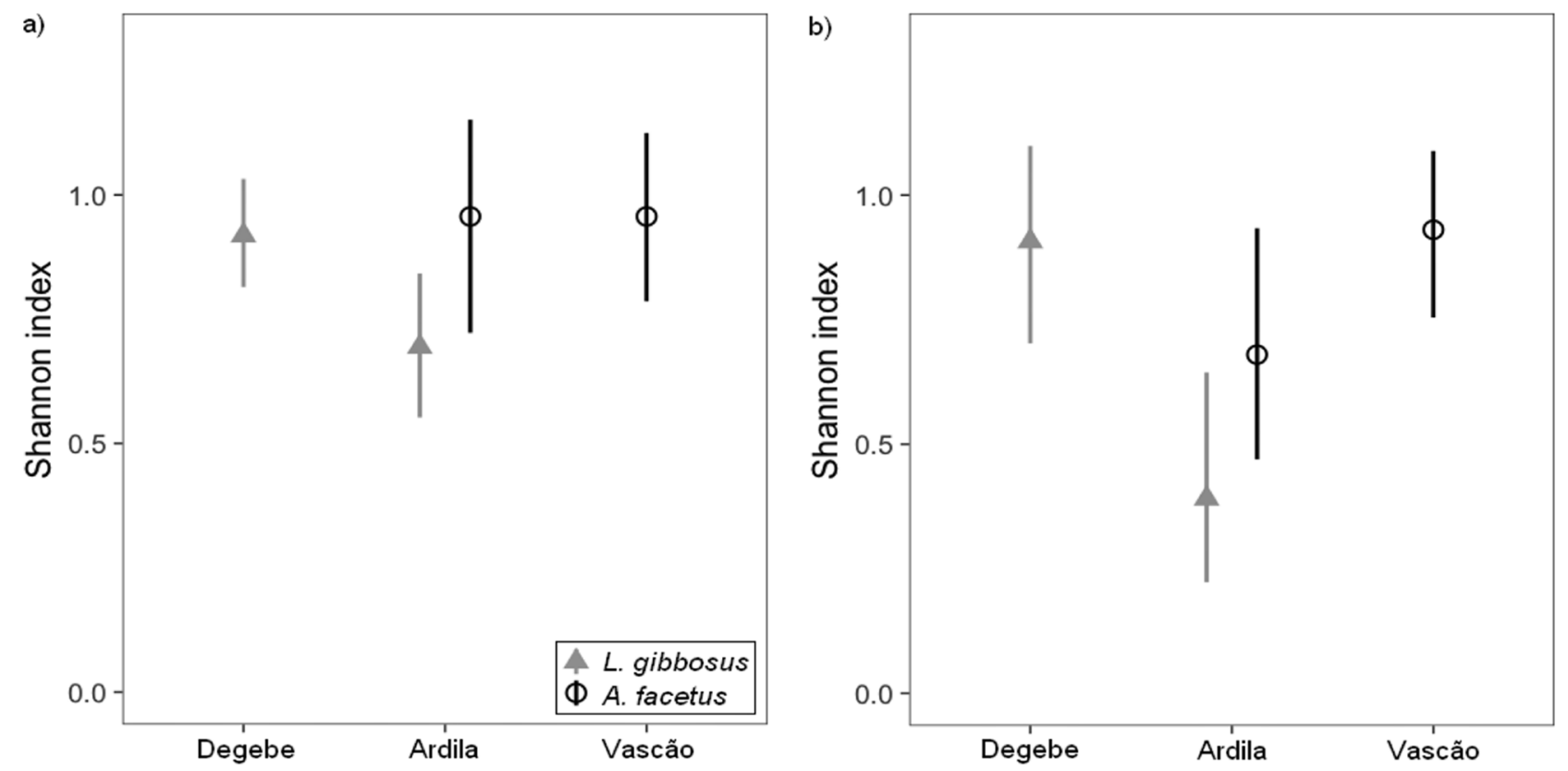

Fig. 4. Dietary niche width based on animal prey in the diet of pumpkinseed Lepomis gibbosus and the cichlid Australoheros facetus in allopatric (Degebe and Vascão) and sympatric (Ardila) sites in the Lower Guadiana Basin (Portugal) during the early (a) and late (b) dry-season. Error bars are the bootstrapped $95 \%$ confidence intervals.

Although there was no change in the use of plant material, sympatric pumpkinseed and the cichlid displayed marked shifts in the use of animal prey and a decrease in niche width relative to their allopatric counterparts. Moreover, in sympatry, pumpkinseed and the cichlid showed similar niche width and some overlap in animal prey but differed markedly in plant material use.

Because it was based on a field-approach, this study was constrained by fish assemblage distribution in the LGB during the dry-season, with invaders generally occurring together with native species and concentrating in the few remaining persistent refuges (Pires et al., 1999). Moreover, to guarantee that model species were sufficiently abundant to yield enough sample sizes and that local assemblages were similar, we were unable to replicate sample locations within rivers. This makes it impossible to characterize the results as occurring broadly or being site specific but minimized the risks of other potentially more serious confounding effects. Although 
differences in the diet of the model species may still reflect at least to some extent their interactions with other species, this was unlikely to have substantial effects in the case of the cichlid because fish assemblages in the Ardila and Vascão were very similar in species composition and abundance. This limitation was potentially more significant in the case of pumpkinseed because mosquitofish was more abundant in the Degebe than in the Ardila river (Ribeiro F., unpublished data), but the latter is a small sized species, that generally prey heavily on zooplankton rather than macroinvertebrates, and thus is unlikely to strongly interact with pumpkinseed with respect to prey type and size (Godinho et al., 1997; Mieiro et al., 2001). Small sample sizes in some sites may also induce some shortcomings to our approach. However, this is unlikely to have any significant effects other than weakening the observed patterns because fish were all in the same range of body length and stomach contained enough prey for analysis. Nevertheless, quantifying trophic niche trajectories during ontogeny should provide additional information about species coexistence.

Variations in dietary niche between allopatry and sympatry observed for both pumpkinseed and the cichlid reflected changes in the use of main prey such as Chironomidae, Ephemeroptera and Hemiptera, but also minor prey such as Ostracoda and Hydracarina. These changes in prey use can be at least partially associated with variations in local prey availability, which were not evaluated in this study. This is an important shortcoming to our approach, given in Mediterranean streams, macroinvertebrate communities generally tend to be more diverse and abundant in permanent than in intermittent sites throughout the dry-season (Pires et al., 2000; Bonada et al., 2007). In particular, we have found a tendency for sympatric fish decreasing niche width in the permanent stream relative to their allopatric counterparts in intermittent streams, which can be associated with higher availability of preferred prey in the former systems. There was, however, no apparent decrease in the consumption of plants by the cichlid in the permanent river despite that prey availability was likely higher (Magalhães, 1993b; Alexandre et al., 2015). This suggests that our findings might not be an artefact of local conditions. Future studies should thus quantify the extent to which prey availability may affect resource use by each species, prey type and size, and the extent to which this may limit species coexistence.

The divergence in dietary niche found for pumpkinseed and the cichlid between allopatry and sympatry is consistent with results obtained for invasive topmouth gudgeon Pseudorasbora parva (Temmnick and Schlegel) and common carp Cyprinus carpio (Linnaeus), which shifted dietary niche composition and decreased niche width when in sympatry with native fish (Tran et al., 2015; Busst and Britton, 2017). However, contrasting patterns have been observed for goldfish Carassius auratus (Linnaeus) which tended to share resources with sympatric native species, though still displayed narrower niches relative to their allopatric counterparts (Britton et al., 2018). Although dietary niche narrowing, rather than niche broadening, might be the pattern in invaded fish communities where resources could otherwise have been limiting (Jackson and Britton, 2014; Tran et al., 2015; Bašić and Britton, 2016), trophic interactions among multiple invaders might be variable, depending at least to some extent on regional and species-specific influences.
Sympatric pumpkinseed and the cichlid showed similar niche width and overlapped in the use of animal prey, but there were still some significant variations in the use of Chironomidae, Hemiptera and Ostracoda. Differences in the contributions of major preys might form an important mechanism reducing interspecific competition (Pompei et al., 2014; Quirino et al., 2015; Olson et al., 2016), especially when sympatric species are likely to share spacerestricted habitats (Magalhães, 1993a; Jackson et al., 2012). Indeed, similar patterns have also been perceived in other studies, with for instance sympatric topmouth gudgeon and common carp strongly partitioning prey (Jackson and Britton, 2014). Slight variations in prey preferences between invasive species as found here might still be important to potentiate some dietary segregation and facilitate coexistence.

Besides variations in animal prey use, sympatric pumpkinseed and the cichlid differed substantially in the use of plant material. Indeed, plant material was of negligible importance in the diet of pumpkinseed but was commonly found and in high proportions in the diet of cichlid. This is consistent with previous studies indicating that plant material is key in the diet of cichlids in native (Gutierrez et al., 1986; Yafe et al., 2002) and invaded areas (Ribeiro et al., 2007), but that pumpkinseed seldom uses this resource in both native (Mittelbach, 1984; Mittelbach et al., 1992) and invaded areas (Godinho et al., 1997; García-Berthou and Moreno-Amich, 2000; Gkenas et al., 2016). This may at least to some extent reflects variations in morphological traits and feeding capabilities between species, as for instance the presence of pharyngeal jaw apparatus in pumpkinseeds may potentiate the use of hardshelled prey relative to other resources (Wainwright, 1996). Regardless of its direct cause, this divergence in plant use may influence trophic interactions between the two species, with advantages for the cichlid. Plant material is a highly accessible and persistent resource in Mediterranean streams (Alexandre et al., 2015) and may constitute an alternative and efficient buffer strategy against prey scarcity (Magalhães, 1993a).

In conclusion, the patterns in dietary niche composition, width, and overlap found for pumpkinseed and the cichlid suggest that divergence in dietary niches may play a role in mediating coexistence of multiple invaders in Iberian streams. This is particularly noteworthy because dietary niche divergence might not only contribute to decrease the risk of competition for shared resources but also result in contrasting impacts between invasive species on recipient ecosystems which remain to be quantified.

\section{Supplementary Material}

Table S1. Environmental characteristics (mean \pm SD) of the three sites in the Lower Guadiana Basin.

The Supplementary Material is available at https://www.kmaejournal.org/10.1051/kmae/2019018/olm.

Acknowledgements. This study was conducted in the frame of the project ISO-INVA co-funded by international funds through Lisboa 2020 - Programa Operacional Regional de Lisboa, in its FEDER component (Project ref. LISBOA01-0145-FEDER-029105) and national funds through FCT Fundação para a Ciência e a Tecnologia, I.P (Project ref. PTDC/CTA-AMB/29105/2017). Additional support was 
provided by FCT through the projects UID/MAR/04292/2019 and UID/BIA/00329/2013, and the post-doc grant (SFRH/ $\mathrm{BPD} / 84859 / 2012$ ) to Christos Gkenas.

\section{References}

Abrams PA. 1983. The theory of limiting similarity. Annu Rev Ecol Syst 14: 359-376.

Alexandre CM, Sales S, Ferreira MT, Almeida PR. 2015. Food resources and cyprinid diet in permanent and temporary Mediterranean rivers with natural and regulated flow. Ecol Freshw Fish 24: 629-645.

Almaça C. 1983. Contemporary changes in Portuguese freshwater fish fauna and conservation of autochthonous Cyprinidae. Roczniki nauk rolniczych, Seria H.T. 100: 9-15.

Almeida D, Merino-Aguirre R, Vilizzi L, Copp GH. 2014. Interspecific aggressive behaviour of invasive pumpkinseed Lepomis gibbosus in Iberian fresh waters. PloS One 9: e88038.

Bašić T, Britton JR. 2016. Characterising the trophic niches of stocked and resident cyprinid fishes: Consistency in partitioning over time, space and body sizes. Ecol Evol 6: 5093-5104.

Bolnick DI, Ingram T, Stutz WE, Snowberg LK, Lau OL, Paull JS. 2010. Ecological release from interspecific competition leads to decoupled changes in population and individual niche width. Proc R Soc Lond B-Biol Sci 277: 1789-1797.

Bonada N, Dolédec S, Statzner B. 2007. Taxonomic and biological trait differences of stream macroinvertebrate communities between Mediterranean and temperate regions: Implications for future climatic scenarios. Glob Change Biol 13: 1658-1671.

Bowen SH. 1996. Quantitative description of the diet. In: Murphy BR, Willis DW, eds. Fisheries techniques. Bethesda, MD: American Fisheries Society, pp. 513-532.

Britton JR, Ruiz-Navarro A, Verreycken H, Amat-Trigo F. 2018. Trophic consequences of introduced species: Comparative impacts of increased interspecific versus intraspecific competitive interactions. Funct Ecol 32: 486-495.

Busst GMA, Britton JR. 2017. Comparative trophic impacts of two globally invasive cyprinid fishes reveal species-specific invasion consequences for a threatened native fish. Freshw Biol 62: 15871595.

Chesson P. 2000. Mechanisms of maintenance of species diversity. Annu Rev Ecol Syst 31: 343-366.

Clarke KR. 1993. Non-parametric multivariate analysis of changes in community structure. Aust J Ecol 18: 117-143.

Clarke KR, Gorley RN, Somerfield PJ, Warwick RM. 2014. Change in marine communities: An approach to statistical analysis and interpretation, 3rd ed. Plymouth: Primer-E Ltd, $256 \mathrm{p}$.

Clavero M, Hermoso V, Levin N, Kark S. 2010. Geograhical linkages between threats and imperilment in freshwater fish in the Mediterranean Basin. Divers Distrib 16: 744-754.

Colwell RK, Futuyma DJ. 1971. On the measurement of niche breadth and overlap. Ecology 52: 567-576.

Cope NJ, Winterbourn MJ. 2004. Competitive interactions between two successful molluscan invaders of freshwaters: An experimental study. Aquat Ecol 38: 83-91.

Creque SM, Czesny SJ. 2012. Diet overlap of non-native alewife with native yellow perch and spottail shiner in nearshore waters of southwestern Lake Michigan, 2000-2007. Ecol Freshw Fish 21: 207-221.

Cucherousset J, Aymes JC, Santoul F, Céréghino R. 2007. Stable isotope evidence of trophic interactions between introduced brook trout (Salvelinus fontinalis) and native brown trout (Salmo trutta) in a mountain stream of southwest France. J Fish Biol 71(Suppl. D): 210-223.

Gabler HM, Amundsen PA. 2010. Feeding strategies, resource utilisation and potential mechanisms for competitive coexistence of Atlantic salmon and alpine bullhead in a sub-Arctic river. Aquat Ecol 44: 325-336.

García-Berthou E, Moreno-Amich R. 2000. Food of introduced pumpkinseed sunfish: Ontogenetic diet shift and seasonal variation. J Fish Biol 57: 29-40.

Gkenas C, Magalhães MF, Cucherousset J, Domingos I, Ribeiro F. 2016. Long term patterns in the late summer dietary niche of the invasive pumpkinseed sunfish Lepomis gibbosus. Knowl Manag Aquat Ecosyst 417: 19.

Godinho F, Ferreira MT, Cortes RV. 1997. The environmental basis of diet variation in pumpkinseed sunfish, Lepomis gibbosus, and largemouth bass, Micropterus salmoides, along an Iberian river basin. Environ Biol Fish 50: 105-115.

Gutierrez M, Bistoni MA, Haro JG. 1986. Hábitos alimentarios de Cichlasoma facetum (Jenyns) (Pisces, Cichlidae) en el Rio Primero (Córdoba, Argentina). Revta Asoc Clenc Nat Lit Santo Tomé 17: 115-126.

Hermoso V, Clavero M. 2011. Threatening processes and conservation management of endemic freshwater fish in the Mediterranean basin: A review. Mar Freshwater Res 62: 244-254.

Jackson MC, Donohue I, Jackson AL, Britton JR, Harper DM, Grey J. 2012. Population-level metrics of dietary structure based on stable isotopes and their application to invasion ecology. PloS One 7: e31757.

Jackson MC, Grey J. 2013. Accelerating rates of freshwater invasions in the catchment of the River Thames. Biol Invasions 15: 945-951.

Jackson MC, Britton JR. 2014. Divergence in the dietary niche of sympatric freshwater invaders. Biol Invasions 16: 1095-1103.

Johnson PT, Olden JD, Solomon CT, Vander Zanden MJ. 2009. Interactions among invaders: Community and ecosystem effects of multiple invasive species in an experimental aquatic system. Oecologia 159: 161-170.

Keddy PA. 1989. Competition. London: Chapman and Hall, 202 p.

Magalhães MF. 1993a. Feeding of an Iberian stream cyprinid assemblage: Seasonality of resource use in a highly variable environment. Oecologia 96: 253-260.

Magalhães MF. 1993b. Effects of season and body-size on the distribution and diet of the Iberian chub Leuciscus pyrenaicus (Gunther) in a lowland catchment. J Fish Biol 42: 875-888.

Magalhães MF, Beja P, Canas C, Collares-Pereira MJ. 2002. Functional heterogeneity of dry-season fish refugia across a Mediterranean catchment: The role of habitat and predation. Freshw Biol 47: 1919-1934.

Mieiro CL, Cabral JA, Marques JC. 2001. Predation pressure of introduced mosquitofish (Gambusia holbrooki Girard), on the native zooplankton community. A case-study from representative habitats in the lower Mondego river Valley (Portugal). Limnetica 20: 279-292.

Mittelbach GG. 1984. Predation and resource partitioning in two sunfishes (Centrarchidae). Ecology 65: 499-513.

Mittelbach GG, Osenberg GW, Wainwright PC. 1992. Variation in resource abundance affects diet and feeding morphology in the pumpkinseed sunfish (Lepomis gibbosus). Oecologia 90: $8-13$.

Olson KW, Jensen OP, Hrabik TR. 2016. Feeding ecology and prey resource partitioning of lenok (Brachymystax lenok) and Baikal grayling (Thymallus arcticus baicalensis) in the Eg and Uur rivers, Mongolia. Ecol Freshw Fish 25: 565-576. 
Orchan Y, Chiron F, Shwartz A, Kark S. 2013. The complex interaction network among multiple invasive bird species in a cavity-nesting community. Biol Invasions 15: 429-445.

Pires AM, Cowx IG, Coelho MM. 1999. Seasonal changes in fish community structure of intermittent streams in the middle reaches of the Guadiana basin, Portugal. J Fish Biol 54: 235-249.

Pires AM, Cowx IG, Coelho MM. 2000. Benthic macroinvertebrate communities of intermittent streams in the middle reaches of the Guadiana Basin (Portugal). Hydrobiologia 435: 167-175.

Pompei L, Giannetto D, Lorenzoni M. 2014. Feeding ecology of Padogobius nigricans (Canestrini, 1987) and Padogobius Bonelli (Bonaparte, 1846) in Aggia River (Umbria, Italy) and their diet overlap. Hydrobiologia 740: 101-113.

Quirino BA, Carniatto N, Gaiotto JV, Fugi R. 2015. Seasonal variation in the use of food resources by small fishes inhabiting the littoral zone in a neotropical floodplain lake. Aquat Ecol 49: 431-440.

R Development Core Team. 2017. R: A language and environment for statistical computing. R Foundation for Statistical Computing, Vienna. http://www.R-project.org.

Ribeiro F, Collares-Pereira MJ. 2010. Life-history variability of nonnative centrarchids in regulated river systems of the lower River Guadiana drainage (south-west Iberian Peninsula). J Fish Biol 76: 522-537.

Ribeiro F, Orjuela RL, Magalhães MF, Collares-Pereira MJ. 2007. Variability in feeding ecology of a South American cichlid: A reason for successful invasion in mediterranean-type rivers? Ecol Freshw Fish 16: 559-569.

Ribeiro F, Elvira B, Collares-Pereira MJ, Moyle PB. 2008. Life-history traits of non-native fishes in Iberian watersheds across several invasion stages: A first approach. Biol Invasions 10: 89-102.

Ribeiro F, Collares-Pereira MJ, Moyle PB. 2009. Non-native fish in the fresh waters of Portugal, Azores and Madeira Islands: A growing threat to aquatic biodiversity. Fish Manag Ecol 16: 255-264.

Ricciardi A. 2001. Facilitative interactions among aquatic invaders: Is an "invasional meltdown" occurring in the Great Lakes? Can J Fish Aquat Sci 58: 2513-2525.

Rios-Cardenas O, Webster AS. 2005. Paternity and paternal effort in the pumpkinseed sunfish. Behav Ecol 16: 914-921.
Rosewarne PJ, Mortimer RJ, Newton RJ, Grocock C, Wing CD, Dunn AM. 2016. Feeding behaviour, predatory functional responses and dietary interactions of the invasive Chinese mitten crab (Eriocheir sinensis) and signal crayfish (Pacifastacus leniusculus). Freshw Biol 61: 426-443.

Ross DJ, Johnson CR, Hewitt CL, Ruiz GM. 2004. Interaction and impacts of two introduced species on a soft-sediment marine assemblage in SE Tasmania. Mar Biol 144: 747-756.

Rothhaupt K-O, Hanselmann AJ, Yohannes E. 2014. Niche differentiation between sympatric alien aquatic crustaceans: An isotopic evidence. Basic Appl Ecol 15: 453-463.

Schoener TW. 1971. Theory of feeding strategies. Annu Rev Ecol Evol S 2: 369-404.

Schoener TW. 1974. Resource partitioning in ecological communities. Science 185: 27-39.

Schoener TW. 1989. The ecological niche. In: Cherrett JM, ed. Oxford: Ecological concepts: The contribution of ecology to an understanding of the natural world, Blackwell Scientific, pp. 79-114.

Seebens H, Blackburn T, Dyer EE, et al. 2017. No saturation in the accumulation of alien species worldwide. Nat Commun 8: 14435.

Simberloff D. 2006. Invasional meltdown 6 years later: Important phenomenon, unfortunate metaphor, or both? Ecol Lett 9: 912-919.

Stephens DW, Krebs JR. 1986. Foraging theory Princeton: Princeton University Press, $247 \mathrm{p}$.

Tran TNQ, Jackson MC, Sheath D, Verreycken H, Britton JR. 2015. Patterns of trophic niche divergence between invasive and native fishes in wild communities are predictable from mesocosm studies. J Anim Ecol 84: 1071-1080.

Vila-Gispert A, Alcaraz C, García-Berthou E. 2005. Life-history traits of invasive fish in small mediterranean streams. Biol Invasions 7: 107-116.

Wainwright PC. 1996. Ecological explanation through functional morphology: The feeding biology of sunfishes. Ecology 77: 1336-1343.

Wiens JA. 1993. Fat times, lean times and competition among predators. Trends Ecol Evol 8: 348-349.

Yafe A, Loureiro M, Scasso F, Quintans F. 2002. Feeding of two Cichlidae species in a hypertrophic urban lake. Iheringia Sér Zool Porto Alegre 92: 73-79.

Cite this article as: Gkenas C, Magalhães MF, Cucherousset J, Orjuela RL, Ribeiro F. 2019. Dietary niche divergence between two invasive fish in Mediterranean streams. Knowl. Manag. Aquat. Ecosyst., 420, 24. 